\title{
DIFERENÇAS NA REGULAÇÃO IÔNICA E NÍVEIS DE OXIHEMOCIANINA ENTRE CALLINECTES DANAE SMITH, 1869 (BRACHYURA: PORTUNIDAE) E C. ORNATUS ORDWAY, 1863 (BRACHYURA: PORTUNIDAE) SIRIS COM DISTRIBUIÇÕES ESTUARINAS DISTINTAS
}

\author{
Rios, L.P. ${ }^{1, *} \&$ Freire, C.A. ${ }^{1}$ \\ ${ }^{1}$ Universidade Federal do Paraná (UFPR), Campus Centro Politécnico, Laboratório de Fisiologia Comparativa \\ da Osmorregulação \\ *Autor correspondente: Ipr2012@gmail.com
}

\begin{abstract}
As espécies de siris Callinectes danae e C. ornatus são encontradas em baías e estuários ao longo da margem oeste do Oceano Atlântico. C. danae ocupa a região mais interna dos estuários, de águas mais diluídas, enquanto $C$. ornatus ocupa a região mais externa, de águas mais salinas. O objetivo desse estudo foi avaliar comparativamente suas características respiratórias e osmorregulatórias, utilizando choques hipo-e hipersalinos de curto prazo, para testar a hipótese de que sua fisiologia está relacionada com a sua distribuição. Os siris foram expostos a choques hiposalino $(10 \%)$ e hipersalino $(40 \%$ o) por $30 \mathrm{~min}, 2$ e 6 h. Uma amostra de hemolinfa foi coletada e dosada para osmolalidade, íons sódio, cloreto, magnésio e potássio, e oxihemocianina. Amostras de tecido muscular e branquial também foram removidas para quantificação de sua hidratação. C. danae demonstrou uma capacidade hiper-regulatória levemente superior ao seu congênere; sua hemolinfa não foi tão diluída como a hemolinfa de C. ornatus, após $6 \mathrm{~h}$ em salinidade $10 \%$. Além disso, $C$. danae mostrou, de forma consistente, maiores concentações de magnésio e cloreto na hemolinfa, em contraste com seus níveis baixos de sódio e oxihemocianina, quando comparados com aqueles encontrados em C. ornatus, praticamente em todas as condições experimentais. Ambas as espécies apresentaram manutenção estrita e similar de hidratação tecidual, nas diferentes salinidades. C. ornatus tem mais oxihemocianina e hiporregula mais magnésio e possui mais sódio na sua hemolinfa do que $C$. danae, que possui mais cloreto. A hipótese de que os siris alteram o seu comportamento para minimizar o contato das brânquias com o meio externo e dessa forma reduzir a sua permeabilidade aparente diante de choque salino não foi confirmada pelos dados de oxihemocianina, que foram estáveis nas diversas salinidades e tempos. Embora as duas espécies pertençam ao mesmo gênero, elas apresentam algumas diferenças ecológicas na sua distribuição, e fisiológicas, na sua regulação iônica e teores de oxihemocianina.
\end{abstract}

Palavras-chave: osmorregulação, decapoda, oxihemocianina. 